\title{
Trialing a new clinical clerkship record in Japanese clinical training
}

This article was published in the following Dove Press journal:

Advances in Medical Education and Practice

22 September 2015

Number of times this article has been viewed

\section{Shosaku Nomura \\ Noboru Tanigawa \\ Yo Kinoshita \\ Koichi Tomoda}

First Department of Internal Medicine, Kansai Medical University, Shinmachi, Hirakata, Osaka, Japan

Correspondence: Shosaku Nomura First Department of Internal Medicine, Kansai Medical University, 2-3-I

Shinmachi, Hirakata,

Osaka 573-II9I, Japan

Tel +8I 728042754

Fax +8I 72804204 I

E-mail nomurash@hirakata.kmu.ac.jp

\section{Dear editor}

Undergraduate medical education has several problems ${ }^{1,2}$ In particular, clinical training, which is the unique feature of medical education, tends to be performed less extensively. In Japan, the current clinical training method is clinical clerkship (CC). CC differs from conventional clinical training, which is study by observation. In $\mathrm{CC}$, the student is a member of the medical team and participates in actual medical care. The student is allowed to practice medical actions in the definite range under the guidance and monitoring of a teaching doctor. Therefore, students can acquire practical clinical abilities. In their study of medical care, students are required to have their own sense of identity and personal responsibility. Clinical training is performed by $\mathrm{CC}$ following the original curriculum for diagnoses and treatments in various medical departments.

The evaluation system is very important in CC. ${ }^{3}$ Student doctors in our school are evaluated using a special checklist, which includes the special training contents and medical actions performed in CC. Students input their practical contents and medical actions into the checklist items, which can then be used in analysis and evaluation. Tutors input their evaluation of their students into the checklist items. Finally, the CC director evaluates these checklists thoroughly.

We devised a CC record (CCR) to be trialed in clinical training (Figure 1). The CCR is a tool to enable $\mathrm{CC}$ to be performed more beneficially and smoothly. Fundamentally, the CCR is not used for evaluation. We never grade CCR comments and we do not examine these comments for promotion. The CCR is an information-transfer system between medical departments. Therefore, the teaching doctors can obtain the students' information from the previous medical department. For example, the tutors or CC director can easily observe students' abilities using computer-based testing and objective structured clinical examination (Figure 1). The CCR was originally for students. The CCR may supplement students' defects and raise their performance levels. The CCR proves to be very useful in identifying students' problems. By drawing attention to students' problems, the CCR enables these issues to be addressed and improves their abilities. Additionally, the CCR has another role, which is to indicate the merit of students. Some examples of positive or negative CCR comments are as follows:

\section{Positive comments}

1. Attitude, action, and motivation are very good.

2. The student's chest X-ray knowledge is fairly good. 


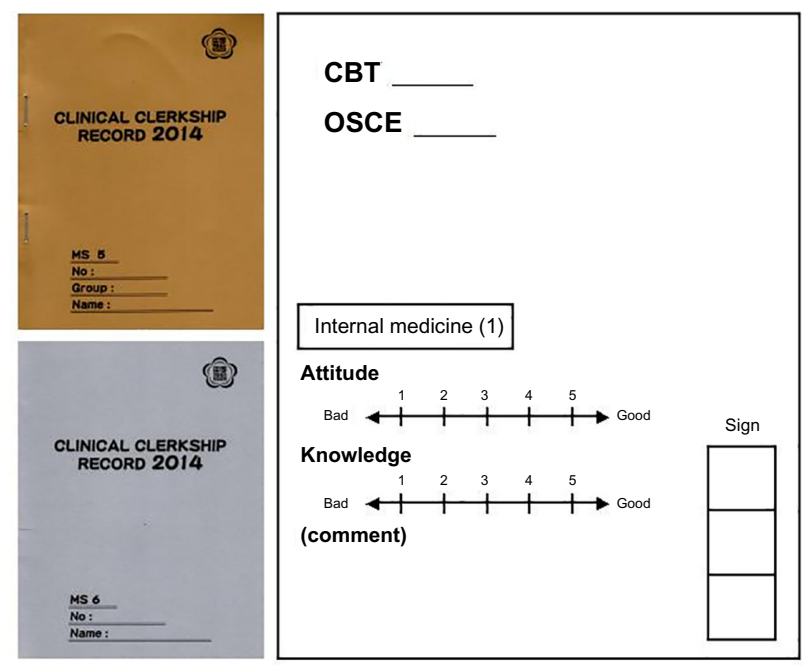

Figure I CC record cover and contents.

Abbreviations: $\mathrm{CC}$, clinical clerkship; $\mathrm{CBT}$, computer-based testing; OSCE, objective structured clinical examination.

3. The student could imagine being a clinical doctor through the communication with patients.

4. The student's attitude to practical training is $\mathrm{OK}$.

5. The student's medical interview was very good.

6. The student can perform medical care and presentation of liver.

7. The student has well-rounded knowledge and practice.

\section{Negative comments}

1. The student needs to increase his knowledge of normal dissection a little.

2. The student needs to systematize her knowledge.

3. Please make an effort to study the dissection of the neck more.

4. It is necessary to perform dissection and physiological learning.

5. Please study differential diagnoses more in depth.

6. Please practice more.

7. Please fully learn the medical care method.

We think that CCRs have some advantages. First, the orientation in CC becomes easier when CCR is used because students can access the CCR during CC. Second, the students' abilities can be objectively known using the CCR. It is very important to identify and evaluate students' abilities during CC. The CCR enables the accurate understanding of students' abilities and delivers appropriate comments to improve students' skills. For example, "you have a shortage of knowledge, which is a problem for your future". However, the CCR also has problems that should be addressed: 1) Students do not input comments into the CCR for their tutors; 2) It is difficult to use the CCR in the field of operations; 3 ) The teaching doctor sometimes finds it difficult to enter negative comments.

Questions play a key role in any CC. Questions stimulate and engage students, help teachers to determine their students' knowledge level and learning needs, and help them monitor how their students are progressing. ${ }^{4,5}$ The questions teachers ask can promote higher-order thinking and encourage reflection. The questions teachers ask and students' responses are also the basis for giving constructive feedback. Therefore, the CCR can provide questions to be asked to enhance clinical reasoning.

Medical education differs considerably from other highereducation settings, which requires the analysis of factors influencing overall student ratings to be focused specifically on medical education. ${ }^{6}$ We have to consider further improvement of the CCR.

\section{Disclosure}

The authors report no conflicts of interest in this communication.

\section{References}

1. Kogan JR, Shea JA. Course evaluation in medical education. Teach Teach Educ. 2007;23:251-264.

2. Gibson KA, Boyle P, Black DA, Cunningham M, Grimm MC, NcNeil HP. Enhancing evaluation in an undergraduate medical education program. Acad Med. 2008;83(8):787-793.

3. Schiekirka S, Reinhardt D, Heim S, et al. Student perceptions of evaluation in undergraduate medical education: a qualitative study from one medical school. BMC Med Educ. 2012;12:45.

4. Scott CS, Hunt DD, Greig LM. Changes in course rating following clinical experiences in the clerkship years. J Med Educ. 1986;61(9):764-766.

5. Bowen JL. Educational strategies to promote clinical diagnostic reasoning. $N$ Engl J Med. 2006;355:2217-2225.

6. Schiekirka S, Raupach T. A systematic review of factors influencing student ratings in undergraduate medical education course evaluations. BMC Med Educ. 2015;15:30. 
Dove Medical Press encourages responsible, free and frank academic debate. The content of the Advances in Medical Education and Practice 'letters to the editor' section does not necessarily represent the views of Dove Medical Press, its officers, agents, employees, related entities or the Advances in Medical Education and Practice editors. While all reasonable steps have been taken to confirm the content of each letter, Dove Medical Press accepts no liability in respect of the content of any letter, nor is it responsible for the content and accuracy of any letter to the editor.

Advances in Medical Education and Practice

Dovepress

\section{Publish your work in this journal}

Advances in Medical Education and Practice is an international, peerreviewed, open access journal that aims to present and publish research on Medical Education covering medical, dental, nursing and allied health care professional education. The journal covers undergraduate education, postgraduate training and continuing medical education including emerging trends and innovative models linking education, research, and health care services. The manuscript management system is completely online and includes a very quick and fair peer-review system. Visit http://www.dovepress.com/testimonials.php to read real quotes from published authors.

Submit your manuscript here: http://www.dovepress.com/advances-in-medical-education-and-practice-journal 